\title{
Redefining the Corporation for a Sustainable New Economy
}

\author{
BEATE SJÅFJELL ${ }^{1}$
}

\begin{abstract}
'Business as usual' is a very certain path towards a very uncertain future. On the 'business as usual' trajectory, the achievement of the UN Sustainable Development Goals (SDGs), epitomising the overarching goals of the global society, is unlikely. A fundamental transition away from 'business as usual' and onto a sustainable path is necessary. However, the SDGs themselves do not seem to be informed by a recognition of a potential conflict between indefinite economic growth and planetary boundaries. This article posits that this is symptomatic of our economic system. With that backdrop, the article turns to the dominant business form: the corporation, to discuss its significance as a barrier to and potential as a driver for sustainability. Drawing on multijurisdictional, comparative research, the article presents a reform proposal, challenging the shareholder primacy drive, and ending on a positive note on the potential of corporate contribution to systemic change.
\end{abstract}

\section{CHALLENGES TO GLOBAL SUSTAINABILITY}

The adoption of the UN Sustainable Development Goals (SDGs) is a promising sign of a consensus in the global community on the necessity of ensuring environmental, social and economic sustainable development. ${ }^{2}$ Yet, it is difficult to envisage that there will be sufficient political will to ensure necessary macro-economic changes quickly enough. This article argues that the SDGs are characterised by a lack of active engagement with that which must after all be assumed to be common knowledge: that we live on one planet and that we are putting the ecological basis of our existence at risk. ${ }^{3}$ Sadly, this appears to be symptomatic of the prevailing

\footnotetext{
${ }^{1}$ Professor Dr. Juris at the University of Oslo Faculty of Law; Professorial Research Fellow at Deakin University Law School; Project Coordinator of Sustainable Market Actors for Responsible Trade (SMART) (smart.uio.no).

${ }^{2}$ United Nations General Assembly resolution 70/1, Transforming Our World: The 2030 Agenda for Sustainable Development, A/RES/70/1, (25 September 2015), available at: www.undocs.org/A/RES/70/1. More information on the SDGs is available here: http://www.un.org/sustainabledevelopment/sustainable-development-goals/ ${ }^{3}$ Science shows us that we are transgressing four out of nine currently identified planetary boundaries; the groundbreaking concept of 'planetary boundaries' was first introduced by J. Rockström et al., 'Planetary Boundaries: Exploring the Safe Operating Space for Humanity' (2009) 14(2) Ecology and Society, <ecologyandsociety.org/vol14/iss2/art32/>, and since revised and updated by W. Steffen et al., 'Planetary University of Oslo, Faculty of Law, Department of Private Law, Postal address: PO Box 6706 St Olavs Plass 5, NO-0130 Oslo, Norway

E-mail: b.k.sjafiell@jus.uio.no

SMART (smart.uio.no) receives funding from the European Union's Horizon 2020 research and innovation programme under Grant Agreement No 693642, and I gratefully acknowledge its support. My warmest thanks to Bronwen Morgan, for organising the colloquium where this article first was presented, to the participants for stimulating discussions, and to the three reviewers for insightful suggestions and constructive criticism, which helped develop the article further.
} 
understanding of our economic system. ${ }^{4}$ The furthest our current mainstream economic system seems to have been able to go is towards a weak version of sustainability, according to which financial value can be maximised using natural resources without the setting of any ecological limits. Illustrative of the dominance of growth- and GDP-focused economic approaches over strong sustainability, which would recognise environmental sustainability as a prerequisite, is also the reaction after the Global Financial Crisis of 2007-2008, with the UN initiative, the 'Global Green New Deal', quickly fizzling out. ${ }^{5}$ In light of this, this article presents the argument that the key to achieving fundamental change quickly enough could be found on the the micro-level: changing the corporation, this vital component of our economies, from within.

In this current Section, the article briefly discusses the conflicted nature of the SDGs as symptomatic of the weak understanding of sustainability on the international political and economic scene. Thereafter, this Section introduces the corporation as the economic actor at the heart of our unsustainable system. ${ }^{6}$ In Section 2 the significance of the corporation and the state-of-the-art knowledge about what shapes the problematic nature of the corporate impact is discussed, while Section 3 turns to the role of law in achieving corporate sustainability, drawing on a tentative proposal for reforming corporate law and corporate governance. Section 4 concludes with reflections on the necessity of systemic change, what this should entail for the follow-up of the SDGs, and the potential of corporate contribution to this change.

In spite of the positive aspect of the SDGs giving a new impetus to the sustainability debate, the SDGs are internally conflicted, and do not properly engage with the crux of the grand challenge of our time: namely how to secure the social foundation for people all over the world now and in the future, while staying with planetary boundaries. ${ }^{7}$ Planetary boundaries as a term used for the limits of our planet is the result of the work of an international multidisciplinary group of environmental scientists, who in 2009 pooled their knowledge of different Earth system processes to inform the world about the space for sustainable action within planetary boundaries. ${ }^{8}$ Their work reflects the growing scientific understanding that life and its physical environment co-evolve. This pioneering effort brought together evidence of rising and interconnected global risks in several different contexts where environmental processes are being changed by human activities. The planetary boundaries framework flags a

\footnotetext{
Boundaries: Guiding Human Development on a Changing Planet' (2015) 347(6223) 1259855 Science <sciencemag.org/content/347/6223/1259855.abstract>.

${ }^{4}$ For an alternative approach, placing economics firmly within planetary boundaries and with the aim of securing a safe and just operating space for humanity, see K. Raworth, Doughnut Economics: Seven Ways to Think Like a 21st-Century Economist, (2017).

${ }^{5}$ UN Environmental Programme (UNEP), 'Global Green New Deal'-Environmentally-Focused Investment Historic Opportunity for 21st Century Prosperity and Job Generation, Press release, 22 October 2008; at $<$ http://www.unep.org/newscentre/Default.aspx?DocumentID=548\&ArticleID=5957>; E.B. Barbier, 'Green stimulus is not sufficient for a global green recovery' Vox, 3 June 2010,

$<$ http://www.voxeu.org/index.php?q=node/5134>. For more about UNEP's more recent green economy efforts: http://www.unep.org/greeneconomy.

${ }^{6}$ Corporation and corporate law are used interchangeably with company and company law.

${ }^{7}$ Rockström, et al., Steffen, et al., op. cit., n. 3.

${ }^{8}$ Rockström et al., Steffen et al., op. cit., n. 3 above. See about the background S. Cornell, 'Planetary Boundaries and Business: putting the operating into the Safe Operating Space for Humanity' (draft paper on file with current author).
} 
set of sustainability-critical issues. It gives a dashboard of issues where our collective humanity is changing the fundamental dynamics of the Earth system most profoundly. ${ }^{9}$

Through the planetary boundaries work it is estimated that humanity has already transgressed or is at risk of transgressing at least four of the currently identified nine planetary boundaries, including climate change, biosphere integrity, biogeochemical flows and landsystem integrity. ${ }^{10}$ The planetary boundaries work is a continuous natural science work-inprogress, as scientists gradually understand more of the complex interactions and feedback mechanisms in the global ecological systems. ${ }^{11}$ Planetary boundaries as a concept forms the rationale by which new boundaries may be identified and better quantifications or metrics adopted. In line with this, the conceptual framework for planetary boundaries itself proposes a strongly precautionary approach, by 'setting the discrete boundary value at the lower and more conservative bound of the uncertainty range'. ${ }^{12}$

That infinite economic growth is not possible on a finite planet is not a new argument, yet its logic is becoming increasingly apparent. ${ }^{13}$ As Tim Jackson points out, infinite economic growth is only possible within planetary boundaries if there is sufficient decoupling of growth from use of natural resources - and he argues convincingly that this appears very unlikely, at least on the current trajectory of our economies. ${ }^{14}$ Rather than taking a firm position on the question of growth, which she argues is akin to staring Medusa in the face, Kate Raworth advocates an agnostic approach. Raworth suggests that we instead discuss how we can achieve an economy that secures social welfare and prosperity across the world and in the future (irrespective of whether economies grow, shrink or level out). ${ }^{15}$ Whether facing the question head on or going about it more indirectly, the (un)sustainability of our current economic system is one of the pervasive issues of our time, and one that cannot be simply ignored. Proper engagement of this issue involves challenging the way economic growth is included amongst that which is to be achieved according to SDG Goal Number 8:

We resolve also to create conditions for sustainable, inclusive and sustained economic growth, shared prosperity and decent work for all, taking into account different levels of national development and capacities. ${ }^{16}$

There is no explanation in the formulation of the SDGs of how it is perceived that sustained (infinite) economic growth is compatible with planetary boundaries, which we are

\footnotetext{
${ }^{9}$ Cornell, id.

${ }^{10}$ The other five being global freshwater use, ocean acidification, atmospheric aerosol loading, stratospheric ozone depletion, and cycling of phosphorus and nitrogen; Steffen et al., op. cit., n. 3.

${ }^{11}$ See also T. Häyhäa, et al., 'From Planetary Boundaries to National Fair Shares of the Global Safe Operating Space - How Can the Scales Be Bridged?’ (2016) 40 Global Environmental Change 60.

${ }^{12}$ Rockström et al., op. cit., n. 3.

${ }^{13}$ D.H. Meadows, et al., The Limits to Growth: The 30-year Update (2004); T. Jackson, Prosperity without Growth: Economics for a Finite Planet, (2017, $2^{\text {nd }}$ edn.); Raworth, op. cit., n. 4.

14 T. Jackson, id.

${ }^{15}$ Raworth, op. cit., n. 4.

${ }^{16}$ United Nations Sustainable Development Goals, United Nations Resolution adopted by the General Assembly on 25 September 2015 , A/RES/70/1 2015, § 70/1: Transforming our world: the 2030 Agenda for Sustainable Development, Declaration item 9 <www.un.org/sustainabledevelopment/sustainable-development-goals/>. Emphasis added.
} 
already putting under increasing stress. Can economic growth be sustainable in an environmental sense? If not, under what conditions and to what extent can economic growth be stimulated in the parts of the world where growth is needed $?^{17}$ And most importantly: how can the global economic system as a whole (to the extent that we can speak about one system; it is of course a set of partly converging and partly competing subsystems) reshape itself into a system that does not take growth as the measurement of success to the extent that any indication of contraction is seen as signalling a risk of imminent collapse?

This is not to say that the SDGs do not repeatedly emphasise the need for 'healing our planet', protecting the environment, the land, the sea, the water and all species in the world. ${ }^{18}$ The problem is that there is no sense of any kind of understanding that there may be a conflict with economic growth, as we know it today, and sustainable development. Item 13 in the Declaration illustrates how the intrinsic and potentially game-stopping contradiction is ignored, in its recognition of the need for a new approach while unreservedly including 'sustained, inclusive and sustainable economic growth' in the definition of sustainable development:

The challenges and commitments identified at these major conferences and summits are interrelated and call for integrated solutions. To address them effectively, a new approach is needed. Sustainable development recognizes that eradicating poverty in all its forms and dimensions, combating inequality within and among countries, preserving the planet, creating sustained, inclusive and sustainable economic growth and fostering social inclusion are linked to each other and are interdependent.

In spite of all the references to environmental issues, there is no mention of the concept of planetary boundaries. The lack of reference to planetary boundaries in the SDGs is not due to lack of information about this work. Indeed, the concept of planetary boundaries was given recognition by the United Nations Secretary General Ban Ki-moon in 2012, when he presented the key points of the report of his High Level Panel on Global Sustainability to an informal plenary meeting of the UN General Assembly. ${ }^{19}$ The concept was incorporated into the socalled 'zero draft' of the outcome of the United Nations Conference on Sustainable Development to be convened in Rio de Janeiro, on 20-22 June 2012. ${ }^{20}$ However, the concept was not included in the final text of the conference, apparently partly due to it being (too) new and partly 'due to concerns from some poorer countries that its adoption could lead to the

\footnotetext{
${ }^{17}$ The SDGs appear to see economic growth in all countries as a goal: 'We envisage a world in which every country enjoys sustained, inclusive and sustainable economic growth and decent work for all'. United Nations Sustainable Development Goals, id.

${ }^{18}$ See for example the Declaration item 9, quoted in text attached to n. 16 above, which goes on to say: 'A world in which consumption and production patterns and use of all natural resources - from air to land, from rivers, lakes and aquifers to oceans and seas - are sustainable', and ends with: 'One in which development and the application of technology are climate-sensitive, respect biodiversity and are resilient. One in which humanity lives in harmony with nature and in which wildlife and other living species are protected'.

19 'Secretary-General Highlights Key Points from Report of His High-level Global Sustainability Panel in Remarks to Informal General Assembly Plenary', SG/SM/14166-GA/11213-ENV/DEV/1263, 16 March 2012 http://www.un.org/press/en/2012/sgsm14166.doc.htm

${ }^{20}$ Y. Sharma, 'Rio+20 zero draft accepts "planetary boundaries"' SciDevNet, 28 March 2012, <http://www.scidev.net/global/water/news/rio-20-zero-draft-accepts-planetary-boundaries-.html>.
} 
sidelining of poverty reduction and economic development' ${ }^{21}$ The latter point does not take into consideration that it is lower-income countries that are the first and the hardest affected by climate change, biodiversity loss and environmental degradation, and who are seen to be the most vulnerable to further environmental degradation. ${ }^{22}$ This unfair distribution is partly caused by geographical location and partly because lower-income countries may tend to have housing and infrastructure that are less resilient, and fewer resources for adaptation and disaster relief. ${ }^{23}$

Lower-income countries have increasingly emphasised this point as well:

'The IPCC makes the case that climate change is real and happening much more strongly than before. We are already seeing the effects of climate change in Bangladesh and across south Asia. It's not news to us. Most developing countries are facing climate change now. They do not need the IPCC to tell them that the weather is changing', said Saleemul Huq, director of the International Centre for Climate Change and Development, based in Dhaka. ${ }^{24}$

There is no necessary contradiction between climate mitigation and other policies to promote environmental sustainability, and policies that reduce poverty and increase social welfare; they may very well be conflated or combined. ${ }^{25}$ Certainly, lack of climate mitigation policies will make poverty reduction and economic development all the more difficult. ${ }^{26}$ Reduction of poverty, like all social aims, existentially depends on us staying within planetary boundaries.

Nevertheless, it may be understandable that the UN decided not to adopt 'planetary boundaries' as its own concept. However, it could have, like the EU, used a different language so as to not commit itself to the work of one group of scientists. In the EU's Seventh Environment Action Programme 'Living well, within the limits of our planet', this vision is formulated:

In 2050, we live well, within the planet's ecological limits. Our prosperity and healthy environment stem from an innovative, circular economy where nothing is wasted and where natural resources are managed sustainably, and biodiversity is protected, valued and restored in ways that enhance our society's resilience. Our low-carbon growth has

\footnotetext{
${ }^{21}$ A. Irwin, 'Your guide to science and technology at Rio+20' SciDevNet, 12 June 2012, <http://www.scidev.net/global/climate-change/feature/your-guide-to-science-and-technology-at-rio-20-1.html>.

${ }^{22}$ J. Vidal 'Climate change will hit poor countries hardest, study shows', The Guardian, 27 September 2013, <https://www.theguardian.com/global-development/2013/sep/27/climate-change-poor-countries-ipcc>, quoting the launch of 2013 IPCC report. See also for example S. Kreft et al., Global Climate Risk Index $2017\left(2017,12^{\text {th }}\right.$ edn.) <https://germanwatch.org/de/download/16411.pdf > .

${ }^{23}$ M. Das Gupta, 'Population, Poverty, and Climate Change' (2014) 29(1) World Bank Research Observer 83; S. Fankhauser and T.K.J. McDermott, 'Understanding the Adaptation Deficit: Why Are Poor Countries More Vulnerable to Climate Events than Rich Countries?', (2014) 27 Global Environmental Change 9.

${ }^{24}$ Vidal, op. cit., n. 22.

25 'Climate Change Complicates Efforts to End Poverty' The World Bank, 6 February 2015, <http://www.worldbank.org/en/news/feature/2015/02/06/climate-change-complicates-efforts-end-poverty>. ${ }^{26} \mathrm{Id}$.
} 
long been decoupled from resource use, setting the pace for a safe and sustainable global society. ${ }^{27}$

As we see, the EU's Environmental Action Plan also uses 'growth' but at least there is an identification of issues to be discussed; notably and implicitly: can growth be totally decoupled from resource use ${ }^{28}$ And there is an explicit recognition of planetary limits, which may be gleaned from the inclusion of the word 'limits' even in the title of the Action Plan. ${ }^{29}$

This explicit recognition of non-negotiable ecological limits, within which our societies and all human, including economic, activity must be positioned for it to be sustainable in the long run, is absent from the SDGs. This is not peculiar to the SDGs but appears rather symptomatic of the mainstream understanding of our economic system and sustainability. The much-lauded Stiglitz Report, commissioned by the UN after the Global Financial Crisis of 2007-2008, is an example of this. While recognising that there are food and water and 'climatic' crises in addition to economic and financial ones, it did not seem to take on board the understanding of ecological limits, with its vision of thinking outside of the box to discuss recommendations for fundamental reforms that were necessary for 'long-term sustainable growth' ${ }^{30}$ The Stiglitz Report and its insightful analyses of the flaws of the macro-economic system and of the financial global architecture have not received the recognition they arguably were due, perhaps because they were perceived as too radical or too difficult to implement. But even if they had been, it seems unlikely that they would have been sufficient to remodel the economy towards one that is sustainable in the full sense of the word, including also the ecological dimension, as long as the goal is one of sustainable growth. In that sense, the Stiglitz Report is nowhere near radical enough, as it does not appear to challenge the fundamentals of an economic system that is threatening our possibilities of achieve a safe and just operating space for humanity. ${ }^{31}$

While this article does not give room for an in-depth discussion of these issues, the above should, together with easily accessible knowledge about the convergence of crises we face, be sufficient to posit: our global economic system appears to be set on a very certain path towards a very uncertain future. Attempts at redesigning the prevailing economic system from one of indefinite growth where increased gross domestic product (GDP) is the measurement of success, regardless of how the GDP increase is achieved, to one that is situated within the ecological limits of our planet and introduces other measures of success, have been met with

\footnotetext{
${ }^{27}$ Environment Action Programme to 2020, Decision No 1386/2013/EU of the European Parliament and of the Council of 20 November 2013 on a General Union Environment Action Programme to 2020 'Living well, within the limits of our planet', OJ/L 354/28 December 2013/171-200.

${ }^{28}$ Recognising that 'Europe's competitiveness and capacity for sustainable growth will depend on improving resource efficiency across the economy', there is also a call for 'indicators and targets for resource efficiency to be established, to guide public and private decision-makers', ibid.

${ }^{29}$ Sadly, also the The European Union's Environment Action Programme is a case in point for the way that the recognition of planetary limits is still one that is relegated to the environmental departments, where it does little good, in the way that it has not been implemented across the policies and activities of the EU.

${ }^{30} \mathrm{~J}$. Stiglitz, et al, The Stiglitz Report: Reforming the International Monetary and Financial Systems in the Wake of the Global Crisis (2011).

${ }^{31}$ M. Leach et al., 'Between Social and Planetary Boundaries: Navigating Pathways in the Safe and Just Pathway for Humanity' in ed. OECD World Social Science Report 2013: Changing Global Environments, pp. 84-90 (2013)<www.worldsocialscience.org/activities/world-social-science-report/the-2013-report/> .
} 
negative reactions ranging from indifference to outrage, and usually coupled with comments on the unrealistic nature of such suggestions. ${ }^{32}$

The corporation is at the heart of this unsustainable economic system. The mantra of maximisation of returns for shareholders is the corporate version of the fixation on economic growth, and is exacerbated through the pressure for highest possible returns amongst institutional investors, and supported by the throw-away consumer society encouraged by corporations (wishing to sell their goods) and politicians (desiring to see their economy grow) alike. Redefining the corporation is arguably key to reinventing a sustainable new economy, as an essential piece of the jigsaw puzzle of sustainability that we urgently need to get into place.

Reforming the corporation needs to start with a discussion on whether and how the dominant business form fits into a sustainable future. This can be rephrased as a question of how to achieve corporate sustainability. In this article, I define corporate sustainability as when businesses (or more broadly, economic actors) in aggregate create value in a manner that is (a) environmentally sustainable in the sense that it ensures the long-term stability and resilience of the ecosystems that support human life, (b) socially sustainable in the sense that it facilitates the respect and promotion of human rights and other basic social rights as well as good governance, and (c) economically sustainable in the sense that it satisfies the economic needs necessary for stable and resilient societies. ${ }^{33}$ The order is not random: environmental sustainability, staying within planetary boundaries, constitutes the framework. ${ }^{34}$

Corporate sustainability is a relatively new theme in corporate law and corporate governance. Management literature has long discussed corporate sustainability; however, the approach of the most influential literature in this area has also been one of 'weak sustainability', resonating with the mainstream approach in economics. ${ }^{35}$ In the corporate law and corporate governance literature, where environmental, social and economic sustainability issues are just beginning to make inroads, the approach is often one of discussing the 'business case' for sustainability, for internalising environmental and social impacts in corporate decision-making as far as this has a positive effect on long-term financial corporate performance. Implicitly, such an approach is also based on one of 'weak sustainability'. The position of this article is that, if it is to be meaningful in identifying how to meet the grand challenge of our time, corporate sustainability must be based on a 'strong sustainability' approach, founded on a natural sciences recognition of non-negotiable planetary boundaries within which all human activity must be positioned to ensure a safe operating space for humanity.

\footnotetext{
${ }^{32}$ Reading T. Jackson, Prosperity without Growth: Economics for a Finite Planet (2009) gives the impression that the fate of the United Kingdom's Sustainable Development Commission may be a case in point, as its recommendations seem to have been perceived as so radical that they had to be hushed down and the Commission eventually shut down. See the archive site: <http://www.sd-commission.org.uk/pages/ourrole.html>.

${ }^{33}$ This definition of corporate sustainability is from the Research Guide in the SMART project (smart.uio.no). ${ }^{34}$ See the insightful analysis of how regulation generally should be positioned within framework in C. Parker and F. Haines, 'An Ecological Approach to Regulatory Studies?', in this special issue.

${ }^{35}$ S. Vildåsen et al., 'Clarifying the Epistemology of Corporate Sustainability' (2017) 138 Ecological Economics 40.
} 


\section{THE SIGNIFICANCE OF THE CORPORATION}

The corporation is the dominant business form. Other forms for doing business, including new and old versions of social entrepreneurship, may contain the potential of being agents for change in the economy. ${ }^{36}$ But if we do not at least also redefine the corporation, we risk social entrepreneurship becoming a moral deflection device, which, if it does become influential enough, may be corporatised, as it is argued that cooperatives have been. ${ }^{37}$ This article presents the multijurisdictional comparative research into corporate law that indicates both why and how the corporation needs to be changed. ${ }^{38}$ This research was conducted by the Sustainable Companies Project, which investigated the barriers to and possibilities for a deeper integration of environmental concerns into the decision-making in corporations. ${ }^{39} \mathrm{We}$ chose to focus on environmental sustainability, recognising that this might be the dimension of sustainability that could be the furthest from corporate decision-making while also being the necessary basis for sustainability as a whole. The main barrier identified was the dominant social norm of shareholder primacy, with its short-term, narrow focus on maximising returns for shareholders. As explained further below, it is crucial to distinguish the social norm of shareholder primacy from the legal norm, found notably in the UK, of shareholder value. That this distinction often has not been made is symptomatic of the dominance of shareholder primacy thinking in corporate law doctrine. ${ }^{40}$

The Sustainable Companies Project investigated core corporate law, through an extensive, comparative analysis of the purpose of the corporation as a matter of law, and the role and duties of the board, as well as that of the general meeting. Because of the board's pivotal role according to corporate law in the strategy-setting and overarching monitoring of the management of the corporation, ${ }^{41}$ the research focused on the concept of the interests of the corporation to find the scope of the board's duty and discretion in its supervision and management of the corporation. The regulation, or lack thereof, of corporate groups also formed part of this investigation. Accounting and auditing law was also investigated in a similar comparative approach, allowing for an in-depth analysis into the areas of law where broader societal interests, through so-called non-financial or Corporate Social Responsibility (CSR) reporting, has made inroads. While the focus of the Sustainable Companies Project was on

\footnotetext{
${ }^{36}$ See N. Boeger, 'Beyond the Shareholder Corporation: Alternative Business Forms and the Contestation of Markets', in this special issue.

${ }^{37}$ Although this trend may now be shifting: see H. Henrÿ, 'Trends and Prospects of Cooperative Law' in eds. D. Cracogna et al., International Handbook of Cooperative Law (2013) 803.

${ }^{38}$ The main results of the Sustainable Companies Project are presented in eds. B. Sjåfjell and B.J. Richardson, Company Law and Sustainability (2015).

${ }^{39}$ The presentation of the results of the corporate law analysis of the Sustainable Companies Project here is based on B. Sjåfjell, et al., 'Shareholder Primacy: The Main Barrier to Sustainable Companies' in eds. B. Sjåfjell and B.J. Richardson, Company Law and Sustainability (2015) 79.

${ }^{40}$ B. Sjåfjell, et al., id.

${ }^{41}$ The board is used in this chapter as a general term encompassing the German Aufsichtsrat, the British board of directors and the board as constituted in the Nordic countries. Trying to fit quite different systems, exemplified by the German two-tier variant and the one-tier system of the UK, into one picture of a board level and a management level requires some simplifications, as the German Aufsichtsrat and the UK board of directors are two quite different things. The German Vorstand ('management board') has some similarities with the UK board that the Aufsichtsrat ('supervisory board') has not, and vice versa.
} 
environmental externalities, the results are to a great extent transferable to social externalities. Indeed, the reform proposal based on this work, summarised briefly below in Section 3, takes that broader view.

In core corporate law, the possibilities for a shift away from business as usual and onto a sustainable path are larger than one might perhaps have initially expected. The mainstream corporate governance debate, which is both informed by and reinforces the shareholder primacy drive, tends to regard maximisation of shareholder profit as the sole purpose of corporations ${ }^{42}$ However, this is, as a matter of law, to a great extent incorrect, especially when one considers society's purpose with corporations in aggregate. While corporate law in some jurisdictions adheres to shareholder value (the legal concept, which we distinguish from the social norm of shareholder primacy), the underlying rationale for facilitating the corporate form through legislation is always that it is thought to be beneficial for society through its contribution to economic development. No corporate law system insists on boards focusing only on returns for shareholders. ${ }^{43}$ All jurisdictions expect boards to ensure legal compliance. We see examples of shareholder value jurisdictions like the UK, expressly stipulating that broader societal concerns should be taken into account. ${ }^{44}$ Generally, corporate law across jurisdictions also allow boards to integrate environmental externalities beyond legal compliance, at least as far as the business case argument allows - that is as far as the case can be made that this is profitable for the corporation in the long run. Within the current system, corporate law on a comparative basis provides perhaps surprising latitude to the board and by extension the management to shape business in a sustainable manner. ${ }^{45}$

However, as is also evident from the state of unsustainability we are in, corporate boards in aggregate clearly do not choose environmentally friendly, low-carbon options within the realm of the business case, let alone challenge the outer boundaries of the scope to pursue profit in a sustainable manner by going beyond the business case. ${ }^{46}$ This is because of the overriding social norm of shareholder primacy, which, supported by management remuneration incentives and other drivers, dictates that board and senior managers are the 'agents' of the shareholders

\footnotetext{
${ }^{42}$ See also S. Healy, 'Corporate Enterprise as Commonwealth', in this special issue, discussing 'business as usual' and shareholder primacy from a theoretical point of view, suggesting with Deakin to reimagine the corporation as a commons managed for multiple parties.

${ }^{43}$ In some jurisdictions environmental sustainability has begun tentatively to make inroads into the explicit duties of the board; see for example A. Johnston, 'Reforming English Company Law to Promote Sustainable Companies', (2014) 11(2) European Company Law 63; T. Lambooy, Corporate Social Responsibility: Legal and Semi-Legal Frameworks Supporting CSR: Developments 2000-2010 and Case Studies, 107-146 (2010). ${ }^{44}$ C. Villiers, 'Sustainable Companies: Barriers and Possibilities in UK Company Law' (2013) 11(1) International and Comparative Corporate Law Journal $105<$ http://ssrn.com/abstract=2280350〉.

${ }^{45}$ This is supported for the institutional investors by the report produced on behalf of the European Commission by Ernst \& Young Cleantech and Sustainability Services (France), 'Resource Efficiency and Fiduciary Duties of Investors', Final Report, ENV.F.1/ETU/2014/0002, DG Environment, (hereinafter EY Report).

${ }^{46}$ The lack of cases challenging the boundaries for how far corporate boards can go in promoting long-term sustainability in their decision-making, is a striking feature in the multijurisdictional comparative analysis presented in Sjåfjell, et al., op. cit., n. 39.
} 
and should maximise returns to shareholders as measured by the current share price. This social norm is so pervasive that it has become a legal myth. ${ }^{47}$

The barrier to corporate sustainability posed by the shareholder primacy norm is exacerbated by the chasm between corporate law's approach to corporate groups and the dominance and practice of such groups. While corporations are 'creatures of national law', ${ }^{48}$ corporate groups are transnational, making a holistic regulation of heterogeneous groups across national borders extremely difficult. The parent company's tight control of the group in practice is perversely matched by the limited legal possibilities for holding the parent company liable for subsidiaries' environmental and social transgressions.

So-called non-financial reporting has become a regulatory tool of choice, not only for the EU, but also for national legislators world-wide, in a desire to influence corporations and their investors to take corporate sustainability issues more into account. Inspired by ideas based on reflexive theory, the compromise solution between those wishing to regulate corporations' environmental and social performance more strictly and those who do not, is asking corporations to report on what they are doing. ${ }^{49}$ In spite of good intentions and much hard work in this area, reporting requirements are insufficient in influencing corporations and their investors. Much reporting remains left to voluntary and discretionary measures, leading to risks of corporate capture, lack of comparability, lack of consistency and uncertainty in benchmarking. ${ }^{50}$ Notably, the new EU non-financial reporting requirements, while they may be perceived as an intermediary step towards the internalisation of social and environmental impacts, currently lack the scope and the necessary verification requirements to be a real gamechanger. $^{51}$

With the shareholder primacy drive thus left mainly unchecked, the resulting general practice of corporations is detrimental to those affected by environmental degradation, violation of human rights and economic exploitation today, and to the possibility for future generations to fulfil their own needs. It is also damaging to the interests of corporations and of shareholders with more than a very short-term perspective on their investment, including institutional investors such as pension funds and sovereign wealth funds. A rising number of investors today allege to have a broader and more long-term focus, including pension funds, which by definition have a very long-term perspective. However, what may be referred to as socially responsible

\footnotetext{
${ }^{47}$ Along with that of shareholders owning corporations, which, as a matter of corporate law, they clearly do not. For an eloquent dismantling of the myth, see P. Ireland 'Company Law and the Myth of Shareholder Ownership' (1999) 62 Modern Law Review, and L. Talbot, Critical Company Law (2nd edn., Routledge, 2015).

${ }^{48}$ As repeatedly emphasised by the Court of Justice of the European Union, see The Queen v H.M. Treasury and Commissioners of Inland Revenue, ex parte Daily Mail and General Trust plc, C-81/87 [1988] ECR 5483, 5511 [19]: 'companies are creatures of the law' and 'exist only by virtue of [...] national legislation which determines their incorporation and functioning'; repeated inter alia in Überseering BV v Nordic Construction Company Baumanagement GmbH, C-208/00 [2002] ECR I-9919, I-9971 [81].

${ }^{49}$ C. Villiers and J. Mähönen, 'Accounting, Auditing and Reporting: Supporting or Obstructing the Sustainable Companies Objective?’ in eds. B. Sjåfjell and B.J. Richardson, Company Law and Sustainability (2015) 175.

${ }^{50}$ Villiers and Mähönen, id.

${ }^{51}$ C. Villiers and J. Mähönen, ‘Article 11: Integrated Reporting or Non-Financial Reporting?’, in eds. B. Sjåfjell and A. Wiesbrock, The Greening of European Business under EU Law (2015) 274.
} 
investing is still a fringe movement, ${ }^{52}$ and institutional investors are generally caught up in a system where misguided efforts at promoting efficiency and maximising value have led to short-term return requirements that exacerbate the narrow, short-term effect of the shareholder primacy drive. ${ }^{53}$ While many institutional investors appear to recognise that, in the long run, they will see the detrimental effects of failing to properly consider broader issues, notably climate change, they are under increasing pressure to maximise returns for beneficiaries in a context of persistently low yields and interest rates.

This negative impact is partly within the scope of the law and partly as a result of violation of the law. The former, the negative impact that is within the scope of the law, is a result of the corporations and the shareholders exploiting the scope the law gives them to maximise short-term returns through an externalisation of environmental and social concerns, by using loopholes and grey areas, and taking advantage of the lack of international regulation of business. The negative impact as a result of violation of the law is an aspect that is often missed in the CSR debate, which speaks about what business and finance should do beyond the law, presupposing legal compliance that is not always present. Talking about what business and investors should do beyond the law serves as a deflection device away from the lack of legal compliance, which may also serve to explain the faith in greater reporting requirements as a mechanism, rather than starting with proper supervision and enforcement of the rules and standards that already are in place. It also reflects persistent belief that markets will self-correct through pressure from investors and corrections to share price where there is misconduct or failure to disclose material information.

\section{CORPORATE REFORM FOR SUSTAINABILITY}

The social norm of shareholder primacy is so strongly entrenched that it has taken on the life of a legal myth, undermining corporate law. This arguably calls for a reform of corporate law, to take back the power of defining what the purpose of corporations is and what the role and duties of the board are. This is not an argument for corporate law taking over the role of environmental law or human rights law, but it is based on a recognition of the limitations of environmental law and human rights law, and the intrinsic problem with silo-thinking, which assumes that various parts of law and policy can act independently while somehow forming a coherent whole.

In previous contributions, I have presented a tentative proposal to reform corporate law, with the aim of contributing to shifting corporations from the unsustainable 'business as usual' and over onto a path of corporate sustainability. ${ }^{54}$ The main content of this tentative reform

\footnotetext{
${ }^{52}$ B.J. Richardson, 'Financial Markets and Socially Responsible Investing', in eds. B. Sjåfjell and B.J. Richardson, Company Law and Sustainability (2015) 227.

${ }^{53}$ In spite of the EY report, for example, op. cit., n. 45, confirming that institutional investors are allowed to take broader societal concerns.

${ }^{54}$ This idea for a reform proposal was in its first version presented together with Jukka Mähönen on the Nordic level, and thereafter, informed by inspiring discussions in the Sustainable Companies team, as a potential EU law proposal; B. Sjåfjell and J. Mähönen, 'Upgrading the Nordic Corporate Governance Model for Sustainable Companies' (2014) 11(2) European Company Law <http://ssrn.com/abstract=2471495>, and B. Sjåfjell,
} 
proposal is to redefine the purpose of the corporation and the role and duties of the board. The reform proposal is informed by the knowledge that if we are to achieve a safe operating space for humanity, we cannot continue with incremental improvements; neither can we focus on whichever environmental or social challenges are given the most attention at any one time. The concept of planetary boundaries, embodying the fundamental recognition of non-negotiable ecological limits for all economic activity and social development, should therefore be a key issue in a redefined purpose of corporations as a matter of corporate law.

Introducing 'planetary boundaries' into corporate law and corporate governance has potential significance on three levels: firstly and most importantly, it brings to the forefront that there are ecological limits (conversely, that being perceived as 'environmentally friendly' is totally inadequate). Secondly, it highlights the complex interaction between planet-level environmental processes and that climate change, for example, while topical (and difficult to mitigate), is only one aspect of the convergence of crises we are heading directly into. Thirdly, it continuously reminds us that state-of-the-art natural science must continue to inform our decisions on a work-in-progress-basis. For corporate decision-makers it therefore should stress the unacceptability of ignorance in the face of these severe environmental risks and the necessity of a knowledge-based precautionary approach. ${ }^{55}$

To redefine corporate purpose in corporate law has the potential to shift corporations away from 'business as usual' short-term maximisation of returns for investors into drivers of a new and truly sustainable economy. Corporate purpose as a legal concept should be to create sustainable value 'within the planetary boundaries'. This clearly signals that these are nonnegotiable boundaries where the room for trade-offs is limited. ${ }^{56}$ To operationalise this redefined purpose it must be integrated into the duties of the board. ${ }^{57}$ As the European Commission has observed, boards have a 'vital part to play in the development of responsible companies ${ }^{58}$ and businesses should:

have in place a process to integrate social, environmental, ethical, human rights and consumer concerns into their business operations and core strategy in close collaboration with their stakeholders, with the aim of: maximising the creation of shared

\footnotetext{
'Corporate Governance for Sustainability: The Necessary Reform of EU Company Law', in eds. B. Sjåfjell and A. Wiesbrock, The Greening of European Business under EU Law (2015) 97, op. cit., 51.

55 See, for example, S. Barker, 'Directors' Personal Liability for Corporate Inaction on Climate Change' (2015) 67(1) Governance Directions 21.

56 This distinguishes the proposal from the much debated 'enlightened shareholder value' in the UK Companies Act (see for example Johnston, op. cit., n. 43, pp. 63-66) and emphasizes the non-negotiable ecological limits as opposed to what is done in the traditional pluralistic approach of Continental-European law. See also, Lambooy, op. cit., n. 43, pp. 107-146.

${ }^{57}$ The duties of the board are arguably the best place in the regulatory ecology of the companies. On the significance of boards see, for example, B. Sjåfjell and L. Anker-Sørensen, 'Directors' Duties and Corporate Social Responsibility (CSR)', in eds. H.S. Birkmose et al., Boards of Directors in European Companies (2013). For a further discussion of the concept of regulatory ecology, see B. Sjåfjell et al., 'Planetary Boundaries and Company Law: Towards a Regulatory Ecology of Corporate Sustainability' University of Oslo Faculty of Law Research Paper No. 2015-11, <http://ssrn.com/abstract=2610583 >.

${ }^{58}$ COM (2011) 681 final, at 5.
} 
value for their owners/shareholders and for their other stakeholders and society at large; and identifying, preventing and mitigating their possible adverse impacts' ${ }^{59}$

Integrating this duty properly into the role of the board would also connect with and serve to better operationalise the environmental precautionary principle and the 'polluter pays' principle. ${ }^{60}$ The board's duty to ensure creation of sustainable value within planetary boundaries should clearly set out a framework for sustainable governance of the business of the corporation, including the full life of the products and processes encompassed in the business, transcending boundaries between legal entities and across global value chains. Such a requirement, designed thoughtfully, would involve a standardisation of a process that corporations wishing to achieve long-term sustainable value would need to do anyway. Standardisation would contribute to lowering costs and establishing a level playing field. Within this framework, such a reform could also promote each company's individual, innovative approach to contributing to corporate sustainability.

A thoughtful set of rules for such a sustainable governance model would give a basis for meaningful reporting and thereby give content to the EU's non-financial reporting directive. ${ }^{61}$ This in turn would provide an informational basis for the apparently growing number of investors that wish to invest sustainably - see, for example, the findings from a global study presented in the MIT Sloan report 'Investing For a Sustainable Future: Investors Care More About Sustainability than Many Executives Believe'. ${ }^{62}$ Shifting capital from fossilfuelled and unsustainable business and onto renewables-based and sustainable enterprises is fundamental to achieving sustainability. Notably, there is an enormous infrastructure funding gap for renewable infrastructure, especially in light of the UN Sustainable Development Goals. ${ }^{63}$ This is highlighted in the request from the Bank of Norway, which manages the largest sovereign wealth fund in the world, the Norwegian Government Pension Fund Global, to be allowed to invest in unlisted infrastructure. Reference is made to the International Energy Agency's estimates that ' 53 trillion dollars in cumulative investment in energy supply and energy efficiency is required over the period to 2035 in order to keep global warming below 2 degrees'. ${ }^{64}$

\footnotetext{
${ }^{59} \mathrm{COM}$ (2011) 681 final, at 6 . The OECD Guidelines for Multinational Enterprises also support the formulation of such duties; OECD, OECD Guidelines for Multinational Enterprises (2011), http://www.oecd.org/corporate/mne/48004323.pdf (accessed 27 June 2016), at 42-46.

${ }^{60}$ See, for example, B. Sjåfjell, 'The Courts as Environmental Champions: The Norwegian Hempel Cases' (2016) 13(5) European Company Law <https://papers.ssrn.com/sol3/papers.cfm?abstract_id=2880514>, and Rockström et al., op. cit., n. 3, on precaution as an intrinsic element of the planetary boundaries approach. ${ }^{61}$ As elaborated on in B. Sjåfjell, 'Bridge Over Troubled Water: Corporate Law Reform for Life-Cycle Based Governance and Reporting', University of Oslo Faculty of Law Research Paper No. 2016-23 <https://ssrn.com/abstract=2874270>.

62 G. Unruh et al., 'Investing for a Sustainable Future. Investors Care More About Sustainability than Many Executives Believe', MIT Sloan Report May 2016, drawing on findings from the 2016 Sustainability \& Innovation Global Executive Study and Research Project. Summary available here: http://sloanreview.mit.edu/projects/investing-for-a-sustainable-future/ ${ }^{63}$ McKinsey Global Institute, 'Bridging Global Infrastructure Gaps' report June 2016, <https://www.mckinsey.de/files/mgi_bridging-global_infrastructure_gaps_june_2016.pdf>.

${ }^{64}$ Norges Bank Investment Management, 'Discussion note 04/2015, Renewable Energy Investments' (2015) at 3 <https://www.nbim.no/contentassets/d4dc0aaf69ba4f73b9112da6bef259c0/nbim_discussionnotes_4-15.pdf>, going on to say that: 'These projections imply annual investments of roughly 2 trillion dollars, or 2 percent of
} 
An alternative to corporate law reform, or at least in a transitional phase, is for businesses to implement such a research-based corporate governance model on a voluntary basis. In the EU-funded project Sustainable Market actors for Responsible Trade (SMART, 2016-2020), this possibility is currently being explored.

\section{THE CORPORATE POTENTIAL FOR SYSTEMIC CHANGE}

Clearly, we are only just at the starting point of a debate that is complex and necessary to have on a systemic level. Resistance may be expected from strong economic forces wishing to preserve the status quo as well as from path-dependent legislators. The UN Sustainable Development Goals appear to express a global consensus for change. The SDGs do not, however, challenge the fundamental assumption that development can and must be based on infinite economic growth. There is nevertheless a gradually emerging recognition that fundamental change is needed, and that that requires a reassessment and rethinking of the relationship between the environment, the economy and society. ${ }^{65}$ The Commission's initiative on Sustainable Finance may signal a willingness to ensure a deeper integration of corporate sustainability into the regulation of business and finance. ${ }^{66}$ Certainly, the interim report of the High-Level Expert Group on Sustainable Finance, focusing as the name indicates on the financial sector, advocates the integration of sustainability into the duties of the board and management, combined with clear and comprehensive reporting, in a way that resonates with the research presented in this article.

Redefining the corporation, this vital component of our economies, offers a possible key to systemic economic change. The shareholder primacy drive and the thinking that informs this drive, has been allowed to dominate for too long. It is detrimental to corporations, to employees, to society and to all investors with more than a narrow and short-term aim of maximum returns. Corporate law reform could realise the potential already existing in current corporate law systems across jurisdictions to create value in and for society in a sustainable manner. Alternatively, or in a transitional phase, it would be possible to implement such research-based corporate governance reform through collaboration between academia and business.

Business shows a willingness to engage with the SDGs, for example through the SDG Business Hub. ${ }^{67}$ However, operationalising the SDGs, also on the micro-level of the individual corporation, cannot be left to business alone - or their consultants. Interdisciplinary research and a systemic approach is necessary to achieve the overarching ambition that informs the SDGs. Academia has a role in interpreting and contributing to operationalising the SDGs in a

\footnotetext{
global GDP per year up to 2030. Although the amount invested has increased over the past few years, the actual invested volume of 1 trillion dollars still falls short of what is deemed necessary. Based on this, one could argue that there is a climate investment gap of 1 trillion dollars per year'.

${ }^{65}$ K. Raworth, op. cit., n. 4. Interesting the EU's latest initiative in the area of Sustainable Finance, see

${ }^{66}$ The High-Level Expert Group on Sustainable Finance appointed by the Commission will present its report by the end of 2017, intended to be a first step towards an EU sustainable finance strategy. See European

Commission, 'Sustainable Finance' (2017) <www.ec.europa.eu/info/business-economy-euro/banking-andfinance/sustainable-finance_en>.

${ }^{67}$ See World Business Council for Sustainable Development, 'SDG Business Hub' (2017) <http://sdghub.com/>.
} 
manner that brings economic and societal development onto a path that leads to a safe and just operating space for humanity. Indeed, in light of the convergences of crises we face, unprecedented collaboration not only within academia but also across academia and society is necessary - and possible. Human creativity and the human potential for collaboration, engagement and change in times of crisis gives hope, after all, for the future. 